\title{
Assessing Leadership And Entrepreneurial Capabilities In A Latin American Youth Program
}

\author{
Michael C. Budden, Southeastern Louisiana University, USA \\ Aristides R. Baraya, Southeastern Louisiana University, USA \\ Connie B. Budden, Southeastern Louisiana University, USA \\ Johana Valero, PEGE Program, Colombia
}

\begin{abstract}
PEGE has now ended its third year. PEGE, a program that encourages students to become contributing members of Society upon graduation from high school instills in participants the tools, techniques and mindset of an entrepreneur. The program initially implemented in an English speaking school located in Bogotá, Colombia is beginning to spread to other schools. Students in the program have evaluated the program and its impact and are uniformly satisfied with the program and recognize its value.
\end{abstract}

Keywords: Entrepreneur; High School; Holistic; PEGE

\section{INTRODUCTION AND BACKGROUND}

s was pointed out by Budden, Baraya and Valero (2012), PEGE recognizes that new paradigms are
arising in the 21 st century that impact communication, business and social realities. These changes
are making social systems more complex to understand and create situations in which solutions to

PEGE (Programa de Emprendimiento y Gestión Empresarial) is an experiential part of a school curriculum that infuses an entrepreneurial mindset with traditional high school subjects. PEGE provides a theoretical base, practical exercises and training to create a learning environment in which students can apply immediately the knowledge they gain in other subjects. Leadership, business management and entrepreneurship skills are all part of the PEGE program. The overriding philosophy is to address student development needs in a holistic fashion and provide opportunities that would not be available through the traditional high school curriculum.

PEGE provides an organized series of theoretical and practical instructions on business management, leadership and entrepreneurship to be incorporated early in a school's curriculum. Ideally, PEGE would be introduced in middle school curriculum and continued through the remainder of a student's secondary education (Budden, Baraya and Valero 2012). The end result would be high school graduates possessing the knowledge, skills and mindset to allow for a the pursuit of higher education if desired, or allow for graduates to recognize business needs and be in a position to pursue the satisfaction of that need through an entrepreneurial venture.

In today's economic environment, one thing is clear - the mindset that when one finishes their education, they will apply for a job somewhere - is quickly becoming a thing of the past. Universally, companies have downsized, right sized, or whatever the latest politically correct term is used to describe the new reality - companies are not hiring as in days of old. Getting out and starting one's own business may be the preferable path for many. 


\section{THE PEGE PROGRAM: A MODEL OF TRANSFORMATION}

For more than 15 years, the Southeastern Louisiana University's College of Business Hispanic Business and Leadership Institute (HBLI) has been working with the Latin American community offering programs designed to support the educational development of Hispanic youth, to provide them a civic and social conscience, and strengthen professional, academic development and business awareness. Through this effort individuals will be able to contribute to society in a better and more productive manner, and advance community wellness. As Sutton-Brady (2006) mentions, relevance and reality are often considered missing from a business education. PEGE attempts to provide both relevance and reality in the learning environment.

Pursuing its mission of advancing the well being of Hispanics in the region, the HBLI started a model program in 2009 to develop leadership and entrepreneurial skills in middle and high school students. A duallanguage school in Bogotá, Colombia was chosen as a beta test site. The program combines education of management and marketing concepts with critical-thinking, practical processes for developing entrepreneurial spirit and knowledge.

The program for entrepreneurship and business management- PEGE - expects students to follow and command traditional disciplines (traditional courses). In addition, the design of the program intends to instill in students a spirit of change and alternative preparation in the administrative sciences, business leadership and management. This way, students will acquire competencies that will allow them to be productive and responsible within the work place. The PEGE program is based on a series of modules that covers the academic period of the student in both middle and high school. A very important and decisive component of this program is the parallel incorporation of the use of TIC's as a basic element for the application of business management systems and concepts; for this the program depends on the support of the HBLI through the use of virtual classes and seminars in which students develop complementary material to their theoretical and practical activities (Budden, Baraya and Valero 2012). As Harbrect, Neidermeyer and Tuten (2006) proffer successful education at US business schools prepares students for the needs of the business environment: a major goal of PEGE.

Currently, the PEGE program prepares students in grades 6 to 11 (in Colombia, students attend school for 11 years). Students are exposed to traditional classroom coursework and a business laboratory in which marketing/management, leadership, technology and entrepreneurship are taught (See Figure 1). The business lab activities require students to establish a business and to manage it for the year. Good citizenship is an expected byproduct of the program. Yates and Ward (2009) believe every college graduate must have a working knowledge of business plans and a greater appreciation of the environment and life of entrepreneurs. PEGE's philosophy is similar, in that the program instills such knowledge even earlier in a student's experience. Products and services are produced and sold. Profits, or the lack thereof provide real-life learning experiences from which students benefit. Profits if made, and they are made, are placed in a bank account for student use at the end of their program. To date, the two graduating classes have used their profits to fund a trip to the US where they are further exposed to business knowledge through a series of lectures on the Southeastern campus, and have a great time traveling to Orlando and even taking a cruise. Thus, students have seen their work and its rewards put to use in furthering their knowledge and providing for a trip of a lifetime.

Each module (course) has a particular subject area that reinforces the driving axes of the program: Marketing, Entrepreneurship, and Management. The theoretical and micro-enterprise assistance components are in the hands of two faculty members. A portion of the virtual component of all of the courses was developed by the HBLI and implemented via distance technologies to students, from the offices of the HBLI in the U.S.

Each class, in grades 6 through 11 manage a micro-business enterprise the students initiate and operate on a continual basis. Sixth grade students offer handcrafts, sandwiches and school events (dances, etc) to the school. Students in $7^{\text {th }}$ grade market refreshments and school souvenirs. They decide on the refreshments to offer and design the souvenirs as well. Students in grade eight design and market greeting cards and prepare and sell a sweet dessert item. Grade nine students have been developing and marketing chocolate covered strawberries and other chocolate treats. Students in grade 10 write, and edit a school newspaper. The students on the newspaper staff also sell advertisements to area businesses to support their effort. And finally, graduating seniors create and market a variety of crepes. 


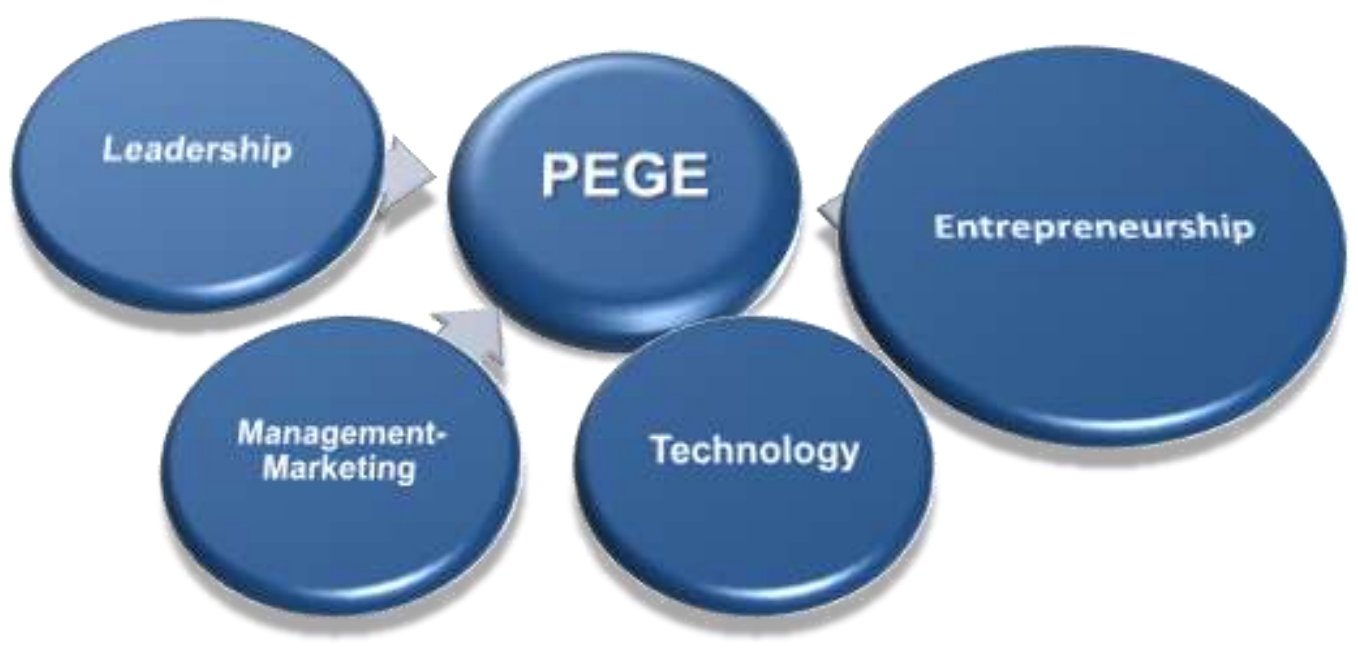

Figure 1

Revenues and expenses are tracked for each enterprise (class). Profits made are retained in each class's account until the students graduate. At that time, accumulated profits will be used to help fund a senior trip to the U.S. So far, the last two such groups of graduates have visited the U.S. They visited New Orleans, Southeastern Louisiana University, the HBLI and Disney World. As an added plus for the College and the HBLI, several PEGE graduates have indicated they will pursue their collegiate education at Southeastern.

\section{ASSESSMENTS}

As part of the program's assessment process, a student opinion questionnaire was administered to program participants by the school. The questionnaire was roughly based on the university's student opinion of teaching questionnaire administered every semester to its students. The scale used was a four-point scale ranging from 1 (weak, not evident) to 4 (strong, very evident). The following table indicates some of the more relevant variables and their associated data. Data is summed across all classes and all participants

Table 1 Student Assessments of PEGE Implementation

\begin{tabular}{|l|c|c|}
\hline \multicolumn{1}{|c|}{ Statement } & Responses (n) & Mean Average \\
\hline $\begin{array}{l}\text { The teacher demonstrated knowledge } \\
\text { and was well-prepared for the class. }\end{array}$ & $2(16) ; 3(158) ; 4(65)$ & 3.21 \\
\hline $\begin{array}{l}\text { The teacher stimulated interest in the } \\
\text { class. }\end{array}$ & $1(3) ; 2(30) ; 3(149) ; 4(57)$ & 3.09 \\
\hline $\begin{array}{l}\text { The teacher was open and responded to } \\
\text { student questions }\end{array}$ & $1(5) ; 2(25) ; 3(136) ; 4(32)$ & 3.16 \\
\hline $\begin{array}{l}\text { Tests and assignments reflected the } \\
\text { course content. }\end{array}$ & $1(4) ; 2(41) ; 3(138) ; 4(56)$ & 3.03 \\
\hline $\begin{array}{l}\text { The teacher provided real world } \\
\text { experiences. }\end{array}$ & $1(4) ; 2(46) ; 3(129) ; 4(60)$ & \multirow{2}{*}{} \\
\hline
\end{tabular}

$\mathrm{N}=239$

The fact that across all students and all classes these measures garnered mean average scores greater than 3.0 was encouraging. Other data findings indicated that students felt the program's objectives were clear (mean 3.05) and that the teacher helped them understand the material (mean 3.0). Students apparently recognize the value of the PEGE program and the role their teachers played in the teaching of it. 


\section{CONCLUSION AND RECOMMENDATIONS}

The PEGE program has given Southeastern's Hispanic Business and Leadership Institute the opportunity to expand its activities to the educational sector in Latin America. The PEGE program is a model that will be replicated. The HBLI has promoted and supported a variety of development activities in Latin America and the PEGE program is deserving of emulation. Already, another school has indicated an interest in setting up a similar program.

PEGE has served as a medium for the students to share their ideas, creativity and experiences and to put them into practice before stepping out to the professional world; as well as developing their potentials as human beings through real experiences while in school.

It's expected that over the next three years the program will have approximately 350 students supporting more than 16 microenterprises. This will allow learning to occur cumulatively over time, reflecting concepts serving as the basis of Bloom's Taxonomy (Stokes, Rosetti and King (2010). Students will not only perform in the academic environment but will support a wide range of community support activities in Bogotá.

\section{AUTHOR INFORMATION}

Dr. Michael Craig Budden is the Candies Professor of Marketing at Southeastern Louisiana University, USA. His research interests include commercial law, ethics, retail control and business education. E-mail: mbudden@selu.edu (Corresponding author)

Dr. Aristides Baraya is the Director of the Hispanic Business and Leadership Institute at Southeastern Louisiana University, USA. His research interests include business development, entrepreneurship and Hispanic development, and leadership. E-mail: abaraya@selu.edu

Ms. Connie B. Budden is an instructor of Management at Southeastern Louisiana University, USA. Her research interests include business education, global business, human resource management issues and business sustainability. E-mail: cbudden@ selu.edu

Ms. Johana Valero is an educator in Colombia. Her interests include youth leadership and advancement, entrepreneurship, and economic advancement. E-mail: jvalero@trade-windsinternational.com

\section{REFERENCES}

1. Budden, M., Baraya, A. R. and Valero, J. I. (2012). Developing Leadership and Entrepreneurial Capabilities in Latin American Youth. Proceedings of the Clute International Conference, pp. 187-190, Rome, Italy.

2. Harbrecht, A., Neidermeyer, P. E. and Tuten, T.L. (2006, October). Changes in Higher Education: How to Address the Learning Needs of the Latino Population. Journal of College Teaching and Learning, 3(10), pp. 63-69.

3. Stokes, L., Rosetti, J.L. and King, M. (2010, November). Form over Substance: Learning Objectives in the Business Core. Contemporary Issues in Education Research, 3(11), pp. 11-20.

4. Sutton-Brady, C. (2006, October). Innovation in Assessment: Injecting Reality into Business Education. Journal of College Teaching and Learning, 3(10), pp. 53-61.

5. Yates, D.A. and Ward, C. (2009, January/February). Staying on the Cutting Edge of Student Active Learning Through Real World Engagement. American Journal of Business Education, 2(1), pp. 101-114. 